\title{
Awareness of Ethics and Integrity at a Malaysian Government District Office
}

Khalidah Khalid Ali *

Department of Management \& Humanities, Universiti Teknologi PETRONAS, Perak, 31750 Malaysia.

\begin{abstract}
The public sector, operated through local/ state governments is the most important instrument in management and administration of a nation. Apart from delivering services and sustaining national development, it is also the social institution entrusted to restore law and order of a nation. These functions and responsibilities indicate direct relationships with morality, ethics and social justice. The district office is the closest level of the government to the people. Hence, issues of ethics and integrity are clearly seen as the people whom they serve directly and who are affected by the government. This paper reports on a pilot study conducted at a district office in Malaysia to investigate employees' responses on awareness initiatives to imbue ethics and integrity at the workplace through a questionnaire with mixed methods. This study has positively found that the district office employees are highly aware of ethics and integrity. They perceive that all initiatives taken at the workplace to create ethical awareness are highly effective and their understanding of ethics and integrity is high (Mean: 4.34 and 4.25 respectively). Posters are viewed to be the most effective medium to create awareness, followed by websites and signages. Superiors, as role models have taken a committed responsibility to remind subordinates through various channels of communication on ethical values and integrity. However, there are still employees who do not seem to be aware of the information provided on ethics. In addition, less than half of the respondents $(46.3 \%)$ are directly involved in the launched ethics campaigns in office. The study findings will draw some insights on effectiveness of initiatives taken at ground level to create ethical awareness among the public-sector employees as Malaysia transforms her socio-economic landscape in the globalization era.
\end{abstract}

Key words: Public sector, Malaysia, ethics, integrity, awareness initiatives

\section{Introduction}

Human values are undergoing change in the past few decades (Khalidah et al., 2012a). The challenges posed towards human values, humanity and human civilization have been even greater since the beginning of the $21^{\text {st }}$ Century, featured by globalization, information and communication technology (ICT), trade liberalization and the free market system. The public sector of a nation forms the government machinery that develops and implements socio-economic policies for the society's prosperity and general well-being.

In fact, the public sector, operated through local/state governments is the most important instrument in management and administration of a nation. Apart from delivering services and sustaining national development, it is also the social institution entrusted to restore law and order of a nation which directly relates to ethics, a study of morality (i.e. right and wrong acts) and social justice. The public sector/local government therefore shoulders a high social responsibility and accountability towards the community at large in the course of providing its services. As any social institution, it is constantly evolving through new leadership, environmental influences and socio-political environment (Article entitled Malaysia: Ethics and Excellent Public Servants. Source: Bernama.com, 18 October, 2014).

The district office, a decentralized set-up within the Malaysian state-government is the closest level of the government to the people. Issues of ethics and integrity are clearly seen as the people whom they serve directly and who are affected by the government. In view of the significance of public service and the pertinent role of the local/state government to imbue ethics and integrity within the civil service employees themselves, an exploratory research has been initiated at a district office in Malaysia to investigate employees' responses on awareness initiatives to imbue ethics and integrity at the workplace.

This study will contribute to the limited value-based studies within the Malaysian context; not to mention the public sector as a whole. It will investigate on public sector employees' awareness on ethics and integrity as well as provide some empirical evidence and insights for the government to assess/ take constructive steps towards instilling ethics and integrity among its employees while balancing economic considerations. At the decentralized level, it will be indicative of the state public service after all the ethics and integrity campaigns at local/ national levels. In addition, it will support

* Corresponding author: khalidah_kh@utp.edu.my 
Perak State government's call to promote an ethical culture in the process of transforming the state's socio-economic landscape under Perak Amanjaya plan.

\section{Literatures and Discussions}

\subsection{Ethics and Integrity in Concepts}

Ethics is derived from the Greek word, ethos which means the character, spirit and attitudes of a group of people or culture (Khalidah et al., 2014; Rahman, 2013). As a concept, it can be described as a set of principles that contains behavioural codes to determine what is right or wrong. Hence, in the study of ethics, one is trying to rationalize what actions are right or wrong and assess whether they are just or fair from different perspectives - individual, organizational and/or societal. To summarize from the writings of Hanafi and Hamid Salam in a book, Islamic Principles of Business Organization and Management, ethics may be defined as a model of behaviour that should be followed in order to harmonize human relationship and minimize abuse and work for the welfare of society (Faridi, 1997).

Integrity, on the other hand, is a virtue (good value) derived from the Latin word integri (Stanwick and Stanwick, 2009). Referring to Oxford Dictionary, integrity relates to honesty and goodness, wholeness and unity. It is an ethical value among many other universally accepted virtues. According to Mohd Tap Salleh (2007), former President of Malaysian Institute of Integrity (Integriti Malaysia), "Integrity is the quality of being honest and upright. It is about individual and organizational characteristics which are perfect based on noble values such as honest, truthful, trustworthy, accountable, transparent, efficient and wise. Individual integrity is the harmony between what he/she says and does. Actions are in accordance with moral and ethical principles as well as laws and regulations and do not go against public interest. They also reflect promptness, correctness and quality."

Ethics relates to character building and development that indeed places on virtues to be emulated in life. While upbringing, socialization process, culture and self- reflections are factors influencing ethics (Khalidah et al., 2012a; Khalidah et al., 2014a; Shaw, 2011), moral objectivists view that religion has a strong influence on individual ethics as it preaches one to embrace fundamental principles and virtues to lead rewarding lives (Weber, 1958; Khalidah et al., 2014b). Malaysia's Rukun Negara/ National Principles directly states the belief in God as a doctrine to be followed by all Malaysians irrespective of religious and cultural differences, implying the importance of religion in Malaysian society despite cultural diversities (Khalidah et al., 2014a). Interestingly, the West, through relativistic thoughts has incorporated religion as a cultural component of a society when the East most often views these two as separate components in practice although we do not deny that religious beliefs do influence a society's cultural landscape (Note: Culture is defined as a set of norms, values and beliefs of a particular group or community and shared by its members (Hofstede,1980). Culture covers a wide spectrum in one's life; from religion to customs and rituals as well as language and membership in ethnic groups (S Awang, M Maros and N. Ibrahim, 2012; Mahathir, 1970; Syed Husin, 2008).

Recognizing the role of religion in shaping ethics while at the same time noting that modernism through industrialization has transformed human civilization since the $19^{\text {th }}$ Century, measured in terms of material well-being, the 1980s and past few decades saw changes in human values and societal norms (Khalidah et al., 2012a; Sharifah Hayaati 2007). Aptly, corruption, ethics and integrity have become contemporary issues in the practice and theory of politics, public administration, law, economics and society nowadays, not only from international contexts but within local contexts. Interestingly, these trends seem to coincide with globalization, introduced in the 1980s and facilitated by information and communication technology (ICT). The ICT/cyber age that we are going through today to some extent influences the way we conduct our lives, not to mention human interactions and values, be it on individual or societal levels. Within the public services environment, "more than ever, citizens are calling for state institutions that are democratic, efficient in the use of public funds, effective in delivering public goods while in the meantime remain strong players in the increasingly competitive global system (Capacity Development Action Briefs by United Nations Development Programme (UNDP) May 2007, Number 2). In another phrase, "the need to build confidence in governments in light of the increased concern on corruption and unethical behavior of their civil servants prompted governments to review their approaches to ethical conduct. There are two broad approaches by which governments attempt to improve public service ethics, i.e. compliance-based ethics management and integrity-based ethics management". 


\subsection{Government Initiatives to Instill Ethics and Integrity in Malaysian Public Service from 1980 onwards}

Malaysia, under Prime Minister Tun Mahathir Mohamad, embarked on a rigorous industrialization policy in the beginning of 1980 s to generate economic growth and social well-being. Alongside industrialization is the greater attention given to ethical/productivity-based concepts. Leading all the efforts to improve the Malaysian Public Service is the Panel for Improvement of the Public Service (PANEL), established in 1986 and headed by the Chief Secretary to the Government. Its role is to "investigate and offer solutions to service problems of common concern. The investigations by PANEL have resulted in several reformed ideas and innovations, not only seen as physical changes but behavioral and attitudinal changes (Sharifah Hayaati, 2011) to accelerate the emulation of virtues and ethics in public service. To name a few, they include enforcement of code of ethics at the workplace, Client Charter, Quality Assurance Standard such as ISO9000, Quality Control Circle and Manual of Work Procedures. The government has also listed ethical values to promote work ethics in the public service. They are quality, productivity, innovativeness, discipline, integration, accountability and professionalism. These values have been introduced through policy formulation such as Look East Policy (1982), Leadership by Example (1983), Name Tags (1985), The Inculcation of Islamic Values Policy (1985), Excellent Work Culture (1989), Clean Efficient and Trustworthy Government (1989) and Vision 2020 (1991) (Noore Alam Siddiquee, 2010; Sharifah Hayaati, 2011).

In fact, Vision 2020, introduced during the Mahathir era sets a new agenda for the future direction of civil servants, i.e. to take the lead role and bring changes not only to the nation's economy but to the community's ethical values. Six core areas have been identified as the major framework/focus for government initiatives on work ethics and values: (1) basic personal values to be imbued i.e. sincerity, trust, self-discipline, commitment, cooperation and moderation; (2) customer-related values i.e. courtesy, humanity, politeness, efficiency and carrying responsibilities expeditiously to fulfill customers' needs; (3) leadership-related values; (4) professional values; (5) productivity and quality values; (6) religious values (Muhammad Rais B Abdul Karim, 1995; Nor 'Azzah Kamri, 2004; Sharifah Hayaati, 2011). These government policies, mostly implemented through awareness campaigns have also been consistently communicated to employees through the chain of commands within the Malaysian public service itself, be it at national and state levels.

Following these, the institutionalization and awareness of ethical values within the society (including public service) continued with the establishment of Malaysian Institute of Integrity (IIM) on 23 April 2004 when Prime Minister Tun Abdullah Ahmad Badawi took office. Its prime objective is to educate and encourage Malaysians at all levels of the society to uphold integrity and embrace noble values as envisaged under the National Integrity Plan (NIP). The NIP is a master plan to develop a fully moral and ethical society whose citizens are strong in religious and spiritual values and imbued with the highest ethical standards. Under the Target 2008, the following missions were identified: effectively reduce corruption, malpractices and abuse of power; increase efficiency in the public delivery system and overcome bureaucratic red tape; enhance corporate governance and business ethics and corporate social responsibility; strengthen the family institution and community and improve the quality of life and people's well-being. The development of National Integrity Plan (NIP) and establishment of IIM have certainly justified the importance of integrity, a virtue to be enculturated and internalized among the Malaysian community as the nation aspires to be developed, in line with Vision 2020.

In April 2009, Prime Minister Datuk Seri Najib Tun Razak introduced the Government Transformation Programme (GTP) and National Key Result Areas (NKRAs) with two main objectives, first, to transform the government to be more effective in its service delivery and be accountable for outcomes that matter most to the rakyat; and second, to help Malaysia move forward to become an advanced, united and just society with high standards of living for all. In fact, eradication of corruption through effective enforcement has been listed as one of the six NKRAs to sustain public sector integrity. The Integrity Pledge was also developed and launched by IIM in 2014 to be internalized by government employees as well as the private sector.

\subsection{Local Studies on Malaysian Public Service}

While government's initiatives to imbue ethics within the public service have been a long way, few local studies have been conducted to link the Malaysian public service with ethics before the millennium. Several were only seen in the last five years (Amalina Abdullah et.al 2014; Baharom Mohamad et al. 2014; Sharifah Hayaati Syed Ismail 2011). To mention some, a study by Noore Alam Siddiquee (2010) on combatting corruption and managing integrity in Malaysia has critically outlined the anti-corruption strategies being followed by the Malaysian civil service and explores the problems and limitations of the current approach to fighting corruption and managing integrity in the society. Tracing from the establishment of Anti-Corruption Agency (ACA) in 1967, the setup of Public Complaints Bureau (PCB) in 1971 until the introduction of National Integrity Plan in 2004 by IIM, the study concluded that corruption has become a 
central issue in Malaysia's political discourse. Evidence shows that despite governmental campaigns and initiatives, corruption remained acute, widespread and worsened in recent years.

Next, a study by Sharifah Hayaati (2011), in attempting to introduce the Effective Governance (EG) as a concept from contemporary and Islamic perspectives have concluded that conceptualizing EG from both dimensions i.e. Islamic and contemporary theories may assist the government in continuously improving public services. Her study concentrated on the role of public service and the process of transition in the move towards EG. It has recognized that with globalization, managing a nation by a virtuous leader is not adequate; it takes the state, private sector and the citizens to ensure effective governance in nation building.

Another quantitative study was conducted by Baharom Mohamad et al. (2014) on 390 Islamic education teachers (IET) to identify the influence of work satisfaction within the perspective of Islam (WSI) through varied dimensions i.e. Spiritual WSI, Intellectual WSI and Material WSI towards work integrity and performance. The study provided an alternative answer on how the integrity of IETs based on work satisfaction from Islamic perspective can determine high work performance. Integrity of IETs is formed through spiritual satisfaction, reasoning and social relationship. This is developed within Islamic education management which balances intellectual, emotional, spiritual and physical aspects of life. While Noore Alam Sidiqque (2010) has walked though the government initiatives to combat corruption as a matter of public ethics and integrity, studies by Sharifah Hayaati (2011) and Baharom et al. (2014) have respectively linked governance and work satisfaction within an Islamic ethical system. Interestingly, a local study by Azharsyah Ibrahim and Nor 'Azzah Kamri (2013) has developed a measurement for Islamic World Ethics (IWE) and, an alternative approach to an available measurement, Protestant Work Ethics (PWE). Earlier academic study in IWE began in early 1980s. The first of such studies was from Naqvi (1981) and Nasr (1984).

\section{The Research Setting and Methodology}

This pilot study was conducted at a branch of a district office in Perak State, Malaysia. Although it reports to the main district office, it is a separate location and given the empowerment to manage its daily activities. Headed by an assistant district officer, this branch has been set up to serve the rural community more efficiently due to the sizable district. It has a total number of 73 employees.

Prior to this study, library research was carried out especially through texts and on-line resources on the Malaysian public service. A survey questionnaire was developed with two sections: Section A to compile demographic data and Section B to gather information on employees' awareness on ethics and integrity at the workplace. Structured interview questions have also been developed and selective interviews followed during the pilot study after gathering questionnaire data from the respondents. However, this paper will only report the findings and analysis from the gathered demographic data in addition to responses on questions related to awareness of ethics and integrity from the questionnaire. The developed questionnaire contains demographic details of respondents, two self- assessed questions on awareness and understanding of workplace ethics by using mean score analysis and 7 added questions to relate the role of media in creating ethical awareness. The 7 added questions are listed below;

1. Have you seen any type of media information on the values of ethics and integrity in the workplace?

2. If you do, what types of the media information?

3. Does your superior remind, through various channels, the values of ethics and integrity while working?

4. What are the examples of behaviours shown by superiors to remind subordinates on the importance of ethics and integrity?

5. Do you know that there are campaigns conducted on importance of ethics and integrity in the workplace?

6. Are you involved in one of the campaigns conducted?

7. Do you recite the Integrity Pledge every month? Write down the Integrity Pledge.

To analyze the demographic data and questions 1, 2, 5, 6, and 7 above, SPSS Version 2.0 was utilized. Mean scores and frequency tests were used for data analysis. Referring to the seven questions above in Section B, except for question 4, all questions have been analyzed by applying frequency tests. For Question 4, the researchers have qualitatively 
analyzed the written comments of respondents through conventional content analysis by counting the most number of responses belonging to categories/themes derived while going through the responses. For question 7 Part 2, (i.e. Write down the Integrity Pledge), the researchers have analyzed and assessed based on the writings of the respondents respectively.

\section{Findings, Analysis and Discussions}

\subsection{Demographic Data}

TABLE 1 below shows the respondents' demographic details.

TABLE 1: Demographic Details of Respondents

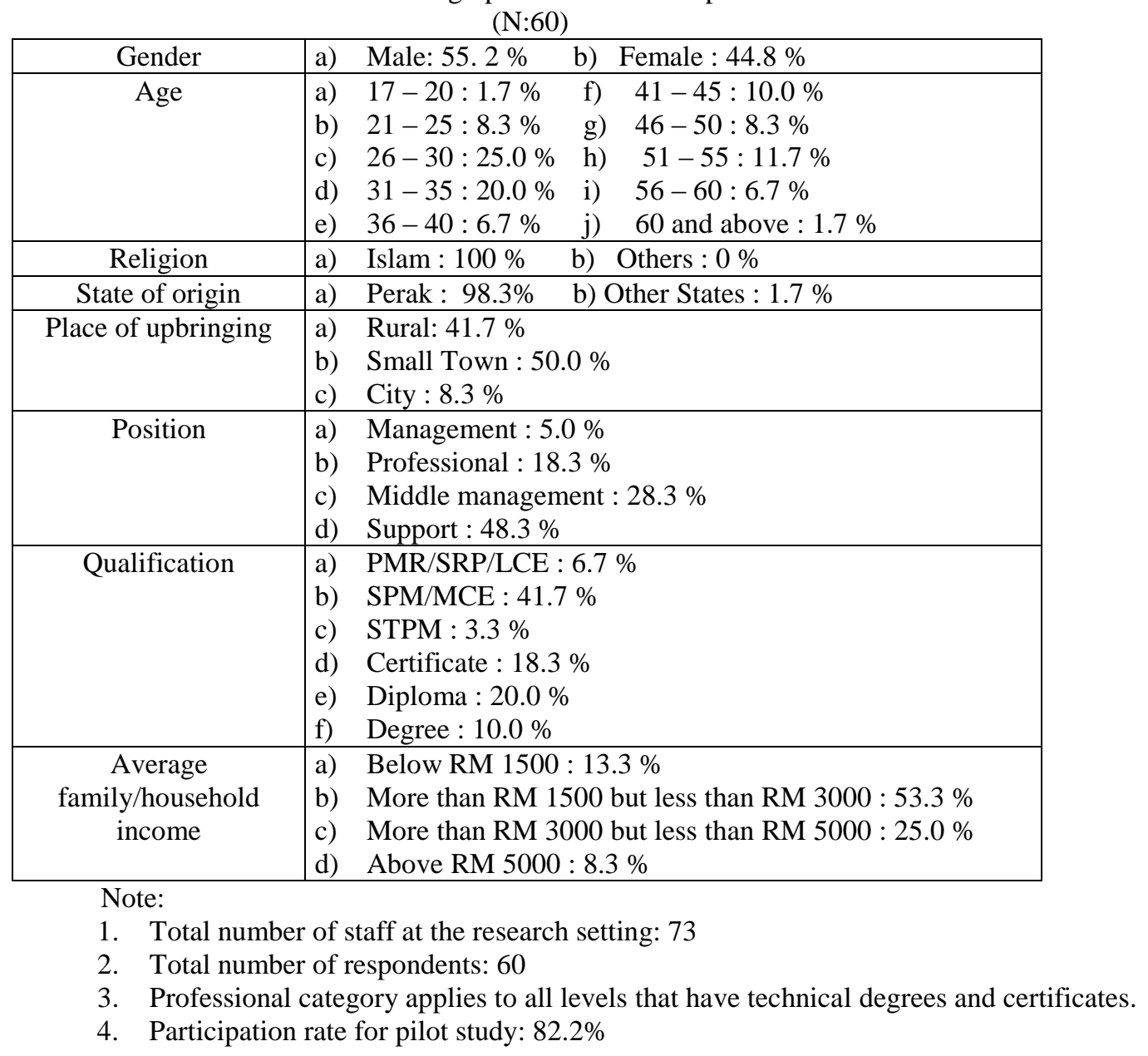

Participation rate for this pilot study is encouraging with $82.2 \%$ respondents. Table 1 shows that although there are more males compared to female employees, the participation rate of women in the workforce is substantial (44.8\%). 55\% of the employees belong to age categories of between 17-35 years of age, implying that majority of the workforce belong to the Generation Y group (i.e. born between 1982-2000). All respondents are Malays and they embrace Islam as a religion. 98.3\% originate from the same state they are serving. More than $90 \%$ of the respondents have been brought up in rural and small towns. An analysis on item (6) above suggests that the organization structure of this branch office is pyramidal/bureaucratic with a majority of support staff $(48.3 \%)$, followed by the middle management and upper management at the top, overseeing the tasks and responsibilities of the lower ranks. Only $18.3 \%$ hold professional qualifications which come with the positions held at the district branch office. In terms of educational background, majority of the employees (41.7\%) hold SPM/MCE qualifications. Only $30 \%$ of the workforce possess tertiary level 
qualifications (i.e. diploma and degree). Assessing their socio-economic status, majority (53.3\%) of the workforce earn an average family/household income of between RM1500-3000. On the other hand, 33.3\% of the respondents earn a household income of RM3000 and above. This implies that more than half of the respondents came from low income groups. (Note: In Malaysia, the definition of urban poverty is a household with a monthly income of RM3000 and below while hardcore poor family is defined as one with a household monthly income of less than RM540 per month. In Peninsular Malaysia, hardcore poverty is further classified; urban- RM663, rural-RM657 and overall- RM657). Demographic data has captured the average household income of respondents since it will be interesting to see their responses on ethical awareness as low income may drive one to compromise on ethics for survival "to make ends meet."

The following section shows the findings on employees' awareness on ethics and integrity.

\subsection{Employees' Awareness of Ethics and Integrity}

TABLE 2: Assessment on Employees’ Awareness and Understanding of Workplace Ethics $(\mathrm{N}=59)$

\begin{tabular}{|c|l|c|c|}
\hline \multicolumn{2}{|c|}{ ITEMS } & Mean & SD \\
\hline 1 & $\begin{array}{l}\text { All initiatives and actions taken at my workplace to create awareness on the } \\
\text { importance of ethics and integrity are effective and impactful }\end{array}$ & 4.34 & 0.685 \\
\hline 2 & I fully understand the concept and meaning of ethics and integrity & 4.25 & 0.685 \\
\hline
\end{tabular}

Employees perceive that all initiatives taken at the workplace to create awareness of ethics and integrity are highly effective and their understanding of ethics and integrity is high (Mean: 4.34 and 4.25 respectively). This is a positive finding on the quality of public sector employees at district level.

The following reveals the findings from the responses on the 7 questions in the questionnaire to investigate the role of media in creating ethical awareness among respondents.

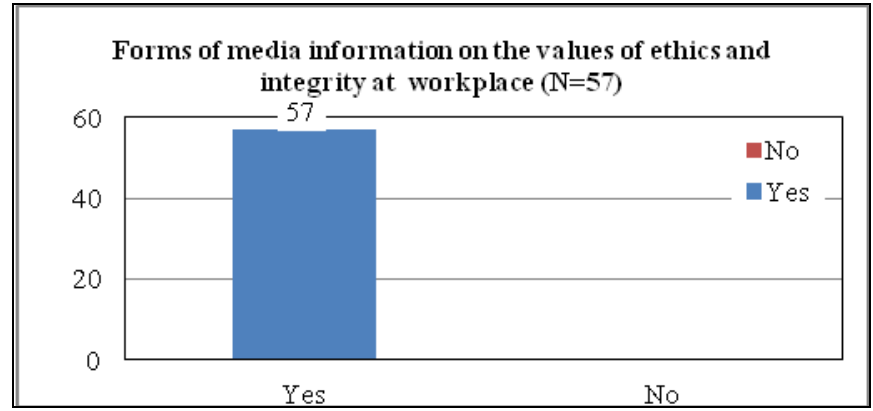

Figure 1: QI- Have you seen any type of media information on the values of ethics and integrity in the workplace?

Most respondents are aware and all have seen media information on ethical values and integrity at their workplace. Nevertheless, although majority have seen them, there are employees who do not seem to be aware of the information provided, indicating ignorance or perhaps indifference towards ethics.

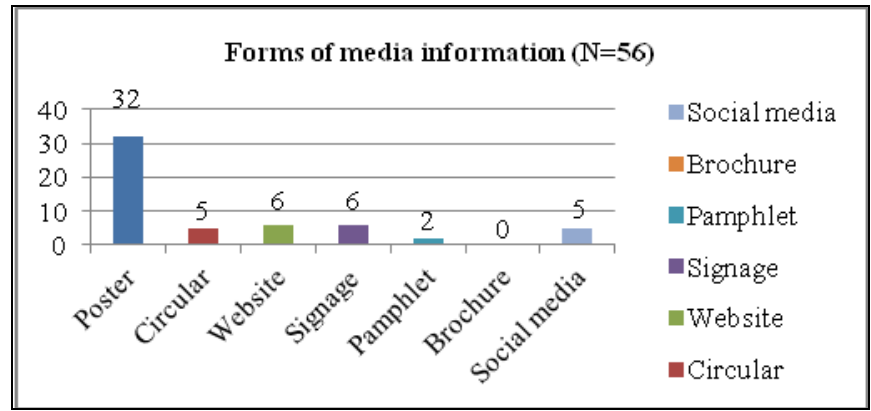


Figure 2: Q2 - If you do, what types of the media information?

$57.1 \%$ of the respondents view that posters are the most visible form followed by websites $(10.7 \%)$ and signages $(10.7 \%)$. This implies that to create ethical awareness, the three mediums may be the most effective at the workplace.

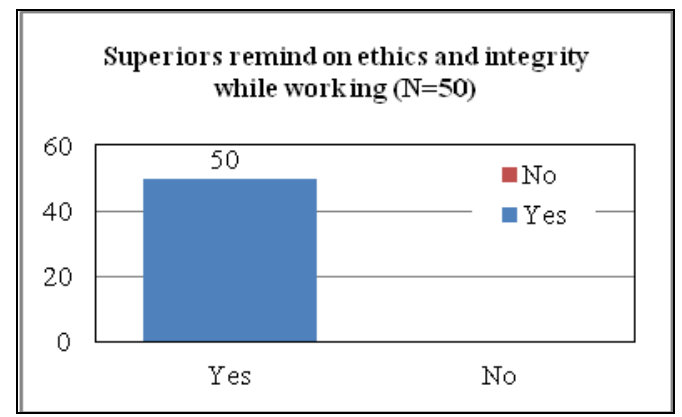

Figure 3: Q3- Does your superior remind, through various channels, the values of ethics and integrity while working?

Respondents also view that superiors have effectively played their leadership roles to remind subordinates through various channels of communication on the importance of applying ethical values and integrity at work.

The following have been found through content analysis on Question 4 (Q4) responses (i.e. What are the examples of behaviours shown by superiors to remind subordinates on the importance of ethics and integrity?);

1) Compliance to punctuality at work and dressing. Leadership by Example.

2) Through face to face communication and reminders to subordinates. This is done through meetings, workshops and addressed speeches.

3) Writings and postings in social media.

4) Subordinates express that superiors display honesty as a value.

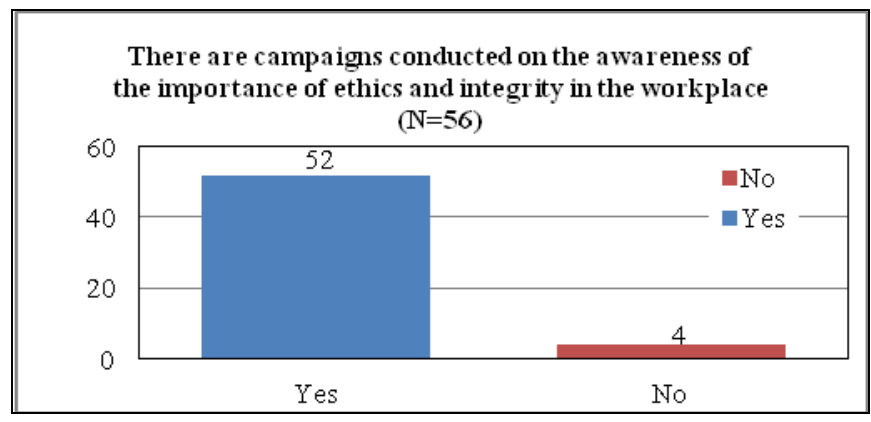

Fig. 5: Q5- Do you know that there are campaigns conducted on the awareness of the importance of ethics and integrity in the workplace?

Most (92.9\%) of the employees are aware of the campaigns on ethics and integrity at the workplace. 


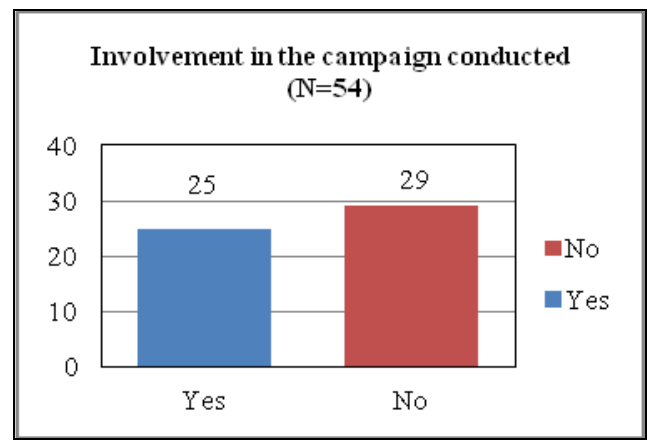

Fig. 6: Q6 - Are you involved in one of the campaigns conducted?

Although employees are aware on the campaigns conducted, only $46.3 \%$ are directly involved in it. This seems to question on their commitment to the campaigns conducted in office.

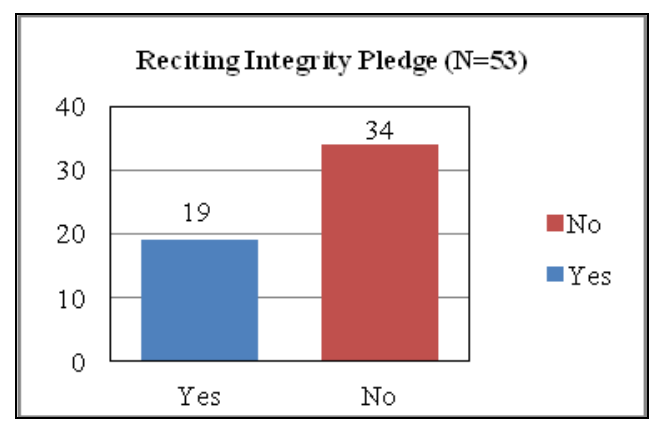

Fig. 7: Q7- Do you recite the Integrity Pledge every month?

Although employees are aware of the Integrity Pledge developed by Institut Integriti Malaysia (IIM) and the launching of a monthly programme to gather employees to recite the Integrity Pledge at the district office, only $35.8 \%$ has participated and recited it at work. In addition, only 5 out of the total sample of 60 respondents (8\%) wrote down the Integrity Pledge as required in the questionnaire. Analysis seems to show employees are not familiar with the Integrity Pledge although they have heard about it, what more to internalize Integrity Pledge at work.

To elaborate further, interview result findings of selected respondents further reveal that employees nowadays do not have sense of urgency and commitment to serve the public. Plausibly, it may imply that initiatives such as the launching of Integrity Pledge is just one of those initiatives that may be regarded as formal but not necessarily fully bought by employees for practice and internalization. Deeper analysis has found that there is clash of views and opinions between upper management and support staff, leading to teamwork problems. Perhaps, these "clashing" environments may lead to indifferent attitudes among employees while the top management is trying to implement the Integrity Pledge at the district office. Furthermore, it is a challenge to make employees internalize good moral values as it is ultimately an individual's responsibility to be good beings or otherwise (Refer to the full study report as listed in No. 4 of the reference list of this paper, page 73). It is also interesting to note that although ethics awareness initiatives (such as Integrity Pledge recitation, reminders by superiors, etc) have been undertaken at the district office level, there are not many courses that are specially organized to seriously address ethics as a discipline to further create ethical conscience among public sector employees.

\section{Conclusion}

This study has positively found that the district office civil service employees in the research setting are highly aware of ethics and integrity initiatives taken at their office. They also perceive that all initiatives at the workplace to create awareness of ethics and integrity are highly effective and their understanding of ethics and integrity is high (Mean: 4.34 and 4.25 respectively). Posters are viewed to be the most effective form of creating awareness, followed by websites and signages. Superiors, as role models seem to take a committed responsibility to remind subordinates through various 
channels of communication on ethical values and integrity at the workplace. Despite these favourable findings, and recognizing that a majority of respondents have seen the various types of media information on ethics and integrity, there are still employees who do not seem to be aware of these information in office. In addition, despite the high awareness among the majority of employees through ethics-related campaigns and other initiatives at the workplace, less than half of the respondents $(46.3 \%)$ are directly involved in the launched campaigns. The Integrity Pledge, introduced by IIM has yet to be made fully aware to employees, what more to be internalized. As ethics relates to moral behaviour that may not be consistently sustained over time, awareness initiatives including talks, forums/dialogues, courses and workshops must be rigorously organized as reminders to employees on the importance of work ethics and ethical conscience in general. There is indeed room for the district office to continue enhancing employees' awareness on ethics and integrity to promote good work values as well as further develop employees' ethical consciousness while serving the community as a social responsibility.

The research team would like to express their heartiest gratitude to Institut Darul Ridzuan Perak (IDR) for the generous allocation of funds to complete this investigation. Appreciation also goes to the district officer and his staff who have given their utmost cooperation and support throughout this research. We are also grateful to Universiti Teknologi PETRONAS management, our family members and colleagues who have given constructive comments, encouragement and continuous moral support throughout this research and publication. The author would also like to acknowledge the contribution of Prof. Dato' Dr. Ahmad Murad bin Noor Merican of Universiti Sains Malaysia for his invaluable advice and guidance in the conduct of this research.

\section{References}

A.A. Hanafi and Hamid Salam (1997), Business Ethics: An Islamic Perspective. Book Chapter in Islamic Principles of Business Organizations and Management. Edited by Dr. F.R. Faridi. Percetakan Sooriya, Kuala Lumpur Malaysia ISBN 883-899-808-7 pp3

Al-Quran; King Fahd Complex: Madinah Munawawarah, K.S.A. For the Printing of the Holy Quran; www.qurancomplex.org

Ahmad Mahdzan Ayob (2004). Malay images in economic affairs: Viewing through the lenses of a Malay. Invited paper presented at the Second International Conference on Malay Civilization held at the Legend Hotel Kuala Lumpur, Malaysia, on 20-28 February 2004 (unpublished) Rahman, A.R.A. (2003), Ethics in Accounting Education, Contribution of the Islamic principle of Maelaiah. IIUM Journal of Economics and Management, 11(1), 1-18

Amalina Abdullah, Zunaidah Sulong and Ridzwana Mohd Said (2014), An Analysis on Ethical Climate and Ethical Judgement among Public Sector Employees in Malaysia, Journal of Applied Business and Economics, Vol. 16 (2).

Articles entitled the Malaysia: Ethics and Excellent Public Servants retrieved from http://www.unpan.org/PublicAdministrationNews/tabid/115/mctl/ArticleView/ModuleID/1467/articleId/23064 /Default.aspx on October 2014

Articles entitled the NIP- Enculturating ethics, noble values and integrity in Malaysian Society retrieved from http://www.iim.org.my/documents/10157/df8450f7-98b0-4591-8570-98c574e7b515 on 20 August 2014.pp. 3

Awareness of Ethics and Integrity at Perak Tengah District Office: A Discourse Study. Universiti Teknologi PETRONAS. Final Report, 30 January, 2015. Research Funded by Institut Darul Ridzuan (IDR), Perak. Azharsyah Ibrahim and Nor 'Azzah Kamri (2013), Measuring the Islamic Work Ethics: An Alternative Approach, International Convention on Islamic Management, Kuala Lumpur, Malaysia.

Baharom Mohamad, Halimatus Saadiah Mat Saad and Sharifah Hayaati Syed Ismail (2014). The Role of Integrity as A Mediator between Work Satisfaction and Work Performance in the Perspective of Islam: An Empirical Approach Using SEM/AMOS Model, International Journal of Research in Applied, Natural and Social Sciences, Vol. 2, pp. 71-84, Jan 2014. 
Case Evidence on "Ethics and Values in Civil Service Reforms", United Nations Development Programme (UNDP), May 2007

Dr. Danial Zainal Abidin, Public Lecture at Universiti Teknologi PETRONAS delivered on 29 July, 2008 in conjunction with the 9th PETRONAS Tilawah Al Quran Assembly (28-29 July, 2008).

Faridi, F.R. (1997), Islamic Principles of Business Organization and Management (Selected Papers of the Seminar of Organizational Behaviour held at Herdon, Virginia, USA, September, 1988), Kuala Lumpur, Malaysia, ISBN 983-899-808-7, S. Abdul Majeed \& Co, p.3).

G. Hofstede (1980), Culture's Consequences: International Differences in Work Related Values, Beverly Hills: Sage Publications.

Green, K (2008). What is Taqwa? Retrieved August 112010 from http://islamicbeliefs.suite101.com /article.cfm/ what_is_taqwa.

H. Mutalib (1993). Islam in Malaysia- From Revivalism to Islamic State. Kent Ridge, Singapore, Singapore University Press, pp17-19.

H. Singh (2001), Ethnic Conflict in Malaysia Revisited. Commonwealth and Comparative Politics, Vol.39, No.1 (March), pp 42-65.

Hafsah Hashim (2014), Business Ethics: The Real Deal. Adjunct Lecture for Universiti Teknologi PETRONAS MBA Energy Management Students delivered on 22 June, 2014.

Integrity (2010). In Oxford Dictionaries Online. Retrieved August 11, 2010 from http://www.oxforddictionaries.com/definition/integrity?view=uk

Khalidah Khalid Ali (1983). M. Sc Research, Malaysia- Looking East for Good Work Ethic submitted as part requirement for the degree of M. Sc (Economics) Industrial Relations and Personnel Management of London School of Economics and Political Science, University of London, September 1983, pp. 5

Khalidah Khalid Ali, Satirenjit Kaur Johl, Lai Fong Woon, Rohani Salleh, Sofiah Molek Lope Aman Shah, Rahayu Abd. Rahman and Ilmiah Ibrahim (2012a). Business Management: A Malaysian Perspective (2nd Ed). Shah Alam, Selangor Darul Ehsan, Malaysia: Oxford Fajar.

Khalidah Khalid Ali, Rohani Salleh and Mashitah Sabdin (2012b). Ethical Values of Final Year Students at a Malaysian Private Higher Learning Institution, 2012 (1) ISSN: 978-1-61275-006-4, published by Information Engineering Research Institute (IERI), USA. Proceedings of International Conference on Applied and Social Science (ICASS 2012), Kuala Lumpur 1 - 2 February, 2012, pp. 119-131.

Khalidah Khalid Ali and Ahmad Murad Merican (2014a). Beyond the Malay Dilemma: Understanding Ethics and Integrity of the Malay Community in Malaysia (1970-2000), ESTCON/ICHSS 2014, Kuala Lumpur, 3-5 June, 2014.

Khalidah Khalid Ali (2014b), The Role of Malay Women in the Malaysian Workforce and its Impact on the Consciousness of Ethics and Integrity. Proceedings of ESTCON/ICLM 2014, Kuala Lumpur, 3-5 June, 2014.

Khalidah Khalid Ali, Zulkufly Ramly and Lau Teck Chai (2014c), Business Ethics, Oxford University Press.

Khalidah, K.A, Rohani, S. and Mashitah, S. (2014d) Ethical Values and Commitment Towards Achieving Excellence: A Study on Public Boarding School Students in Malaysia. Pertanika Journal of Social Sciences and Humanities. 22 (S), pp. 33-50.

Mahathir Mohamad (1970 and 1977), The Malay Dilemma, Kuala Lumpur: Pelanduk Publications.

Monthly Statistical Bulletin Malaysia, (On line), Available: http://www.statistics.gv.my/portal/index retrieved December, 2011. 
Muhamad bin Ahmad (2009). The Influence of Culture on Malay Muslim Business Practice: A Case Study of Malaysia with Special Reference to the State of Kelantan Dar al-Naim. A Thesis submitted to University of Birmingham for the degree of Doctor of Philosophy 2009. pp 51-58.

Muhammad Rais B Abdul Karim (1995), Improving the Efficiency of The Public Sector: A Case Study of Malaysia, United Nations.

Nor' Azzah Kamri and Khairiah Salwa Haji Mokhtar (2004), The Role of Islamic Ethics in Organizations: An Experience in Malaysia. Paper presented at $6^{\text {th }}$ ASEAN Inter-University Seminar on Social Development organized by School of Social Science, Universiti Sains Malaysia (USM) and University of Singapore at University Sains Malaysia, Penang, Malaysia, 14-16 May, 2004.

Noore Alam Siddiquee (2010). Combating Corruption and Managing Integrity in Malaysia: A Critical Overview of Recent Strategies and Initiatives, Springer Science.

Othman Mohd Yunus, Nur Hamizah Hamzah and Mohd Afandi Abu Bakar (2011), Religiousity and Work Values Orientation of Malaysian Malay Businesspersons. Proceedings of Eighth International Conference on Islamic Economics and Finance - Sustainable Growth and Inclusive. 19-21 December 2011. Doha Qatar.

Rahman, A.R.A (2003). Ethics in Accounting Education: Contribution of Islamic Principle of Maelaiah. IIUM Journal of Economics and Management, 11 (1): 1-18.

S. Awang, M. Maros, and N. Ibrahim (2012). Malay Values in Intercultural Communication, International Journal of Social Science and Humanity, Vol. 2, No. 3, May 2012.

Sharifah Hayaati Syed Ismail (2007), Values and Ethics Towards Quality Public Delivery System of Malaysia: An Islamic Perspective, Jurnal Syariah, Vol 15(2), pp. 25-43.

Sharifah Hayaati Syed Ismail (2011). Role and Transition of Public Service in Malaysia: An Effective Governance Perspective, African Journal of Business Management, Vol. 5(5), pp. 1963-1975, March 2011

Shaw, W.H. (2011). Business Ethics (7th Ed.). Belmont, CA: Thompson Wadsworth.

S.N.H. Naqvi (1981), Ethics and Economics: An Islamic Synthesis, Islamic Foundation, Leicester, UK.

S.H. Nasr (1984), Islamic Work Ethic, Hamdard Islamicus, Vol. 7, pp. 25-35.

Stanwick, P.A. and Stanwick S.D. (2009). Understanding Business Ethics, New Jersey: Pearson International Edition.

Syed Husin Ali (2008), Ethnic Relations in Malaysia- Harmony and Conflict, Strategic Information and Research Development Centre, Vinlin Press Sdn Bhd., Selangor, Malaysia.

Syed Husin Ali (2008), Ethnic Relations in Malaysia- Harmony and Conflict, Strategic Information and Research Development Centre, Vinlin Press Sdn Bhd., Selangor, Malaysia.

Syed Othman and H.G. Aidit, Islamic Values and Management. Kuala Lumpur, Malaysia. Institute of Islamic Understanding Malaysia (IKIM), 1994.

Weber, M. (1958). The Protestant ethic and the spirit of capitalism. (T. Parsons, Trans.). New York: Charles Scribner's Sons. (Original work published as two separate essays, $1904-1905)$.

Zahazan Mohamed and Muhammad Zakaria, 2011) Hadith Riwayat Muslim no.8, Abu Daud no.4695, al -Tirmizi no. 2738 and al- Nasai no 8/97 with minor difference; sourced from Hadith 40 Imam Nawawi 